\title{
STUDI LITERATUR: KEBUTUHAN PELAYANAAN KESEHATAN YANG BELUM TERPENUHI PADA PENYINTAS KANKER GINEKOLOGI
}

\author{
Selly Kresna Dewi ${ }^{\bowtie}$, Margaretha Martini
}

Sekolah Tinggi Ilmu Kesehatan Suaka Insan Banjarmasin

\begin{tabular}{l}
\hline ARTICLE INFO \\
\hline Article history \\
Submitted : 2021-04-05 \\
Revised : 2021-11-26 \\
Accepted : 2021-12-21 \\
\hline Keywords: \\
Unmeet need \\
Supportive Care \\
Survivor cancer \\
Gynecology \\
Kata Kunci: \\
Unmeet need \\
Perawatan Suportif \\
Penyintas kanker \\
Ginekologi
\end{tabular}

\begin{abstract}
There is an urgent increase of health care needs for cancer survivor nowadays caused by the escalations of global cancer survivor's unmet need for cancer care health services. The purpose of this literature study was to identify the gynecology cancer survivor's unmet need of health care services. A literature search was PRISMA for relevant research paper. Six database were searched: Proquest, Elsevier, Spinger, Wiley Online Library, and Google Scholar using keyword: "CaSUN", "SCNS-SF34", "Unmet need"," Survivor cancer", "Supportive care", Cancer Gynecological". The final review included 9 articles from 993 article that being identified from $2015-2020$. The result of this study was minimum 1 unmet need found in every gynecology cancer survivor, psychological needs and information on health services, physical and sexual needs.
\end{abstract}

\begin{abstract}
Kebutuhan pelayanan kesehatan pada penyintas kanker saat ini mengalami peningkatan. Penyintas kanker setiap tahunnya mengalami peningkatan sehingga secara fakta kebutuhan pelayanan kanker belum terpenuhi, sehingga memengaruhi kualitas hidup penyintas kanker ginekologi. Tujuan telaah literatur ini untuk mengidentifikasi kebutuhan pelayanan kesehatan pada penyintas kanker ginekologi. Metode yang digunakan menggunakan pendekatan PRISMA dengan pencarian Google Scholar, Web of Sciences: (ProQuest, Springerlink,Wiley, Elsevier) pencarian artikel dimulai dari tahun 2015 - 2020 dengan kata kunci yaitu "CaSUN", "supportive care needs survey short form 34 (SCNS-SF34), "Unmet need"," Survivor cancer", "Supportive care", Cancer Gynecological". Didapatkan hasil sebanyak 9 artikel penelitian masuk dalam kriteria inklusi dari 993 yang diidentifikasi melalui proses skrining melalui penelusuran literatur, memilih artikel yang duplikat serta artikel yang full text. Kesimpulan yang didapatkan yaitu penyintas kanker ginekologi memiliki minimal satu kebutuhan yang tidak terpenuhi. Dari keseluruhan hasil yang didapatkan bahwa kebutuhan yang masih banyak belum terpenuhi adalah pada kebutuhan secara psikologi dan informasi pelayanan kesehatan, fisik dan kebutuhan seksual.
\end{abstract}

Corresponding Author:

Selly Kresna Dewi

Sekolah Tinggi Ilmu Kesehatan Suaka Insan Banjarmasin

Telp. 08111804909

Email: sellyjendra@gmail.com

\section{PENDAHULUAN}

Kanker dan perawatannya yang terjadi pada perempuan secara signifikan dapat memengaruhi kualitas hidup yang berhubungan dengan kesehatannya. Banyak masalah yang dialami perempuan penyintas kanker mulai saat terdiagnosis awal hingga terapi modalitas dilakukan. Penyintas kanker hidup dengan rasa ketidakpastian dari saat diagnosis (Khan, Rose, \& Evans, 2012; Truant, Fitch, Oleary, \& Stewart, 2017).

Kebutuhan pelayanan kesehatan pada penyintas kanker saat ini mengalami peningkatan, dimana penyintas kanker semakin meningkat dari 39\% hingga $70 \%$ setiap tahunnya (American Cancer Society, 2018). Faktanya kebutuhan pelayanan kesehatan penyintas kanker ginekologi menghadapi kenyataan hidup bahwa kehidupan setelah kanker lebih banyak memiliki masalah kesehatan fisik maupun emosional yang belum terpenuhi (Truant, Fitch, Leary, \& Stewart, 2017).

Pada tatanan pelayanan kesehatan seharusnya memberikan pelayanan kesehatan yang holistik tidak terkecuali pada para penyintas kanker. Penyintas kanker diidentifikasi memiliki beberapa kebutuhan 
yang belum terpenuhi (Hediya Putri, Afiyanti, Ungsianik, \& Milanti, 2018; McCallum et al., 2014; Ozga et al., 2013; Simard et al., 2013). Kebutuhan manusia tidak hanya terbatas pada kebutuhan secara fisik saja tetapi masih ada kebutuhan emosional, seksualitas, ekonomi, informasi, sosial, psikologi dan spiritual (Zhu et al., 2018).

Kebutuhan perawatan suportif yang tidak terpenuhi dapat berkontribusi pada tekanan emosional dan memengaruhi kualitas hidup para penyintas kanker (Fitch, Porter, \& Beverley, 2009). Banyak faktor yang memengaruhi kebutuhan tersebut sehingga dengan melakukan telaah literatur ini dapat membantu mengetahui kebutuhan penyintas kanker ginekologi tidak terpenuhi.

\section{METODE PENELITIAN Jenis Penelitian}

Metode penelitian yang digunakan adalah dengan studi literatur. Pencarian secara sistematis didasarkan pada pernyataan Preferred Reporting Items for Systematis Review and Meta-Analysis (PRISMA). Kata kunci yang digunakan dalam pencarian yaitu Cancer Survivor's Unmet Needs (CaSUN), Supportive Care Needs Survey Shosrt Form 34 (SCNS-SF34) Unmeet need, Survivor/survivorship cancer, Supportive care, Gynecological.

Untuk menjawab kata kunci digunakan artikel penelitian yang dimulai sejak 2015 2020. Lingkup pencarian artikel pada studi kuantitatif. Untuk mengumpulkan data digunakan Proquest, Elsevier, Springer, Wiley Online Library dan Google Scholar.

\section{Kriteria Inklusi}

Selain menggunakan kata kunci, yaitu menggunakan kriteria inklusi: Penyintas kanker ginekologi, selesai tahap pengobatan kanker, studi kuantitatif, jumlah sampel $>100$ responden, menggunakan bahasa Inggris serta artikel fulltext dengan sumber yang relevan. Dari pencarian 2624 artikel.

\section{Ekstraksi data}

Keseluruhan artikel diidentifikasi dan disaring untuk menilai kelayakan berdasarkan judul, abstrak dan kriteria yang dibuat. 64 artikel didapatkan dan 125 artikel dikeluarkan dengan alasan: tidak berhubungan dengan topik (7), bukan penyintas kanker ginekologi (32), artikel tidak menggunakan metode cross sectional (11), metode yang digunakan dengan hasil tidak relevan (2).

\section{Risiko Bias}

Penilaian risiko bias dari penelitian yang identifikasi yaitu menggunakan Cochrane risk of bias assessment tool from: "Assesing risk of bias in included studies" oleh JPT Higgins, DG Altman, dan JAC Sterne, dalam Cochrane Handbook for Systematic Review of intervensi (versi 5.1.0).

\section{Figure 1. PRISMA Flow Chart-Details of study flow}

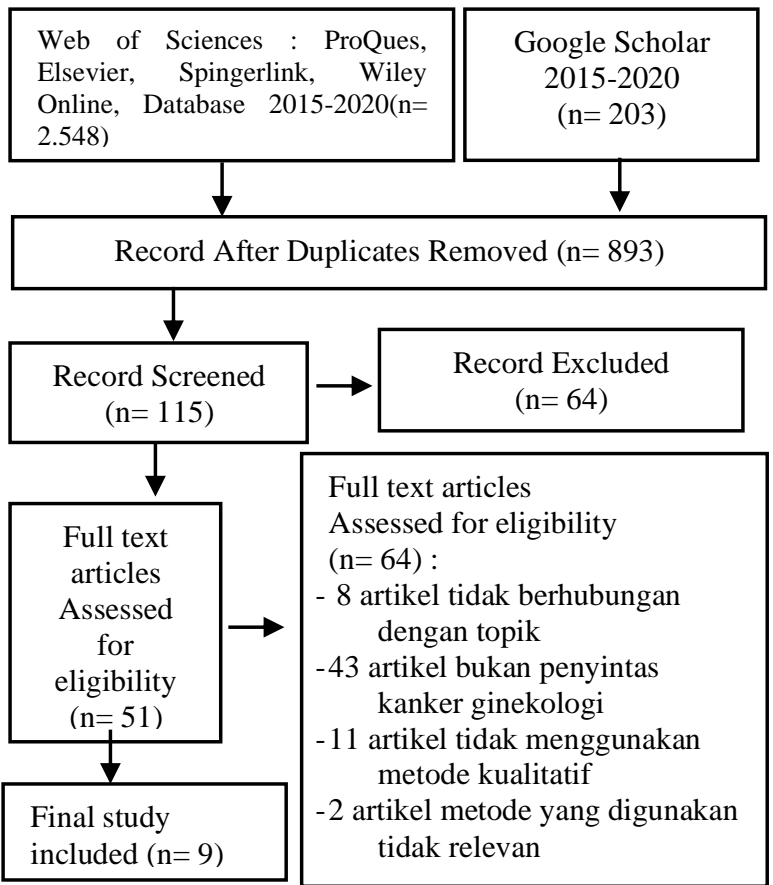

\section{HASIL PENELITIAN}

Berdasarkan studi karakteristik terdapat 12 artikel yang sesuai dengan karakteristik yang ditentukan. Semua artikel yang terpilih sesuai dengan kriteria inklusi yaitu: mulai dari 20152020, penyintas kanker ginekologi, selesai tahapan pengobatan terapi kanker, studi cross sectional, jumlah sampel >100 responden, menggunakan bahasa Inggris serta artikel fulltext dengan sumber yang relevan. Hasil pengumpulan data menggunakan kata kunci, Casun cancer, SCNS-SF 34, Unmeet need, Supportive care need, Cancer gynecological, Survivor cancer.

Kebutuhan para penyintas kanker ginekologi dari sembilan artikel didapatkan hasil jika ada beberapa kebutuhan tidak 
terpenuhi dan ada 2 kebutuhan yang dominan tidak terpenuhi setelah menyelesaikan terapi pengobatan kanker yaitu domain psikologis, pelayanan informasi, informasi pelayanan kesehatan, dan kebutuhan seksual. Matrik ringkasan dari studi yang dimasukkan dalam telaah (tabel 1):

Tabel 1. Matrix Ringkasan Studi tentang Kebutuhan Pelayanan Kesehatan yang Belum Terpenuhi pada Penyintas Kanker Ginekologi

\begin{tabular}{|c|c|c|c|c|c|}
\hline Penulis & Tahun & Design & $\begin{array}{l}\text { Jumlah } \\
\text { sampel }\end{array}$ & Fokus utama & Hasil Yankes Belum Terpenuhi \\
\hline $\begin{array}{l}\text { Doubova \& } \\
\text { Perez-Cuevas }\end{array}$ & 2020 & $\begin{array}{c}\text { Cross } \\
\text { Sectional }\end{array}$ & $\begin{array}{l}165 \\
\text { responden }\end{array}$ & $\begin{array}{l}\text { Mengidentifikasi kebutuhan } \\
\text { supportive care yang paling } \\
\text { dibutuhkan pada pasien } \\
\text { kanker serviks di Mexico }\end{array}$ & $\begin{array}{l}41,2 \% \text { penyintas kanker serviks } \\
\text { membutuhkan pelayanan secara } \\
\text { psikologis terkait dengan kondisi } \\
\text { depresi pada penyintas kanker } \\
\text { serviks. }\end{array}$ \\
\hline Cho et al & 2020 & $\begin{array}{l}\text { Descriptive, } \\
\text { cross- } \\
\text { sectional } \\
\text { study } \\
\end{array}$ & $\begin{array}{c}228 \\
\text { responden }\end{array}$ & $\begin{array}{l}\text { Mengidentifikasi kebutuhan } \\
\text { belum terpenuhi setelah } \\
\text { selesai treatment } \\
\text { pengobatan kanker }\end{array}$ & $\begin{array}{l}40 \% \text { penyintas } \text { kanker } \\
\text { mengkhawatirkan kebutuhan } \\
\text { seksual mereka yang belum } \\
\text { terpenuhi. }\end{array}$ \\
\hline $\begin{array}{l}\text { Pongthavornkamol, } \\
\text { Lekdamrongkul, } \\
\text { Pinsuntorn, \& } \\
\text { Molassiotis }\end{array}$ & 2019 & $\begin{array}{c}\text { Cross } \\
\text { Sectional }\end{array}$ & $\begin{array}{c}236 \\
\text { responden }\end{array}$ & $\begin{array}{l}\text { Melihat kebutuhan } \\
\text { supportive care oleh } \\
\text { penyintas kanker ginekologi } \\
\text { di Thailand }\end{array}$ & $\begin{array}{l}\text { Kebutuhan secara fisik memang } \\
\text { sering terjadi tetapi kebutuhan } \\
\text { secara psikologis terkait } \\
\text { ketakutan kambuh } 44,5 \% \\
\text { menyumbang angka yang paling } \\
\text { besar. }\end{array}$ \\
\hline Afiyanti, \& Gayatri & 2019 & $\begin{array}{l}\text { Survey } \\
\text { Cross } \\
\text { Sectional }\end{array}$ & $\begin{array}{c}298 \\
\text { responden }\end{array}$ & $\begin{array}{lr}\text { Menilai } & \text { kebutuhan } \\
\text { perawatan suportif yang } \\
\text { tidak terpenuhi pada pasien } \\
\text { kanker ginekologi di } \\
\text { Indonesia }\end{array}$ & 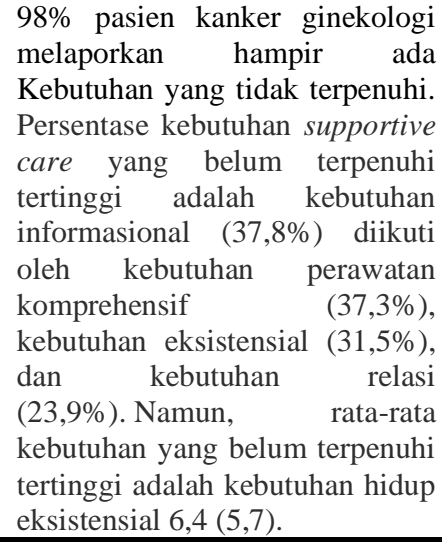 \\
\hline Li, et al., & 2018 & $\begin{array}{l}\text { Cross } \\
\text { Sectional } \\
\text { Study }\end{array}$ & $\begin{array}{c}363 \\
\text { responden }\end{array}$ & $\begin{array}{lr}\text { Mengetahui } & \text { kebutuhan } \\
\text { perawatan suportif yang } \\
\text { tidak terpenuhi penderita } \\
\text { kanker dan } & \text { untuk } \\
\text { mengidentifikasi } & \text { faktor } \\
\text { yang terkait kebutuhan } \\
\text { suportif yang } r \text { belum } \\
\text { terpenuhi dari penderita } \\
\text { kanker }\end{array}$ & $\begin{array}{l}\text { Tingkat kebutuhan perawatan } \\
\text { suportif yang tidak terpenuhi } \\
\text { (kebutuhan sedang dan kuat) } \\
\text { berkisar antara 12,1 hingga } \\
59,1 \% \text {. Lima kebutuhan yang } \\
\text { belum terpenuhi termasuk } \\
\text { kekhawatiran tentang kanker } \\
\text { yang muncul kembali }(59,1 \%) \text {, } \\
\text { mengakses perawatan medis } \\
\text { terbaik (52,7\%), mengakses } \\
\text { layanan terapi komplementer } \\
(51,5 \%) \text {, perubahan kepercayaan } \\
(48,2 \%), \text { dan harapan yang } \\
\text { selamat }(47,6 \%) \text {. }\end{array}$ \\
\hline $\begin{array}{l}\text { Williams, Griffin, } \\
\text { Farrell, Rea, } \\
\text { Murray, \& Hauck, }\end{array}$ & 2018 & $\begin{array}{l}\text { Cross } \\
\text { Sectional } \\
\quad \text { study }\end{array}$ & $\begin{array}{c}303 \\
\text { responden }\end{array}$ & $\begin{array}{l}\text { Mengidentifikasi kebutuhan } \\
\text { perawatan suportif } \\
\text { perempuan di Australia } \\
\text { yang mengalami kanker } \\
\text { ginekologi dan kepuasan } \\
\text { mereka terhadap pelayanan } \\
\text { kesehatan }\end{array}$ & $\begin{array}{l}\text { Penyintas kanker ginekologi } \\
83 \% \text { memiliki minimal satu } \\
\text { kebutuhan suportif yang tidak } \\
\text { terpenuhi. Kebutuhan yang } \\
\text { terbesar adalah pada domain } \\
\text { pelayanan kesehatan } \\
\text { informasi dan } \\
\text { ketakutan kambuh } \\
\text { psikologi yaitu }(53,7 \%) \text { domain }\end{array}$ \\
\hline
\end{tabular}




\begin{tabular}{|c|c|c|c|c|c|}
\hline Penulis & Tahun & Design & $\begin{array}{l}\text { Jumlah } \\
\text { sampel }\end{array}$ & Fokus utama & Hasil Yankes Belum Terpenuhi \\
\hline $\begin{array}{l}\text { Rietveld, Husson, \& } \\
\text { Vos }\end{array}$ & 2017 & $\begin{array}{c}\text { Cross } \\
\text { Sectional } \\
\text { study }\end{array}$ & $\begin{array}{c}348 \\
\text { responden }\end{array}$ & $\begin{array}{l}\text { Mengidentifikasi hubungan } \\
\text { antara kepuasan dengan } \\
\text { penyediaan informasi } \\
\text { selama diagnosis dan } \\
\text { perawatan, kebutuhan } \\
\text { perawatan suportif pada } \\
\text { penderita kanker ovarium. }\end{array}$ & $\begin{array}{l}\text { Kebutuhan akan informasi } \\
\text { sangat dibutuhkan pada } \\
\text { survivorship dan banyak yang } \\
\text { puas tentang penyediaan } \\
\text { informasi tersebut bagi } \\
\text { kesehatan penyintas kanker. }\end{array}$ \\
\hline Zhu et al & 2018 & $\begin{array}{c}\text { Cross } \\
\text { Sectional } \\
\text { study }\end{array}$ & $\begin{array}{c}301 \\
\text { responden }\end{array}$ & $\begin{array}{l}\text { Mengidentifikasi kebutuhan } \\
\text { yang belum terpenuhi pada } \\
\text { penyintas kanker di China }\end{array}$ & $\begin{array}{l}\text { Kebutuhan yang belum dan } \\
\text { paling tinggi skoringnya adalah } \\
\text { pada domain psikologi, } \\
\text { pelayanan kesehatan dan } \\
\text { informasi, Sedangkan secara } \\
\text { fisik dan seksual memiliki skor } \\
\text { yang terendah bagi survivor. }\end{array}$ \\
\hline
\end{tabular}

Berdasarkan tabel matriks pada salah satu studi didapatkan hasil bahwa $96.1 \%$ penyintas kanker memiliki kebutuhan yang tidak terpenuhi, kebutuhan yang dominan tidak terpenuhi terdapat pada domain psikologi, pelayanan kesehatan dan informasi pelayanan, kemudian dilanjutkan dengan ditemukannya domain fisik, sosial, seksual dan spiritual meskipun nilainya rendah. Kebutuhan penyintas kanker ginekologi bervariasi dan berbeda setiap individu berdasarkan sosio demografinya, seperti usia ( $\mathrm{Li}$ et al., 2018; Rowland, Janda, Mckinnon, Webb dan Beesley, 2015). Hasil studi lainnya mengatakan bahwa para penyintas kanker memiliki setidaknya satu kebutuhan yang tidak terpenuhi. Kebutuhan tersebut yang paling sering adalah kondisi psikologi, kebutuhan pelayanan kesehatan terkait informasi pelayanan. Penyintas kanker ginekologi yang hanya memiliki satu saja kebutuhan yang tidak terpenuhi dikaitkan dengan kondisi yang kemungkinan akan dialami seperti cemas, depresi, stres, dan jika terus menerus terjadi dapat menurunkan kualitas hidupnya sekitar 41,2\% (Afiyanti, Milanti dan Putri, 2018; Urbaniec, Collins, Denson dan Whitford, 2011; Doubova dan Perez Cuevas, 2020).

Kebutuhan yang belum terpenuhi pada domain kondisi psikologis berhubungan dengan keadaan sedih, tertekan, cemas dan para penyintas juga sangat khawatir tentang perawatan berada diluar kendali mereka sehingga muncul pikiran-pikiran tentang tentang kematian, ketidakpastian tentang masa depan, mencoba mengendalikan situasi, ketakutan penyakit akan kambuh dan menyebar ke tempat lainnya sekitar $53,7 \%$ (Pongthavornkamol, Lekdamrongkul,
Pinsuntorn, \& Molassiotis, 2019: Williams, Griffin, Farrell, Rea, Murray, \& Hauck, 2018).

Hasil studi tersebut pada domain psikologi didukung oleh beberapa studi lainnya ada sekitar $23 \%$ penyintas kanker takut kanker kembali lagi dan yang mengatakan rasa takut kambuh itu sampai 59,1 \%, kanker akan menyebar kembali, khawatir juga tentang orang-orang terdekatnya sekitar $18 \%$. Penyintas kanker juga berpikir tentang kematian sekitar $17 \%$ yang lainnya takut akan kecacatan secara fisik (Li et al., 2018; McCallum et al., 2014).

Pada domain pelayanan dan informasi kesehatan penyintas kanker memiliki kebutuhan yang perlu dipenuhi yaitu informasi tentang penyakit kanker mereka terkendali atau berkurang, mendapat informasi tentang efek samping setelah semua pengobatan selesai dilakukan, diberikan penjelasan yang lebih rinci tentang manfaat melakukan pemeriksaan rutin, saat melakukan pemeriksaan di pelayanan kesehatan selalu dianggap penyakit yang berbeda dari penyakit yang lainnya, perlunya informasi tentang pengelolaan penyakit atau efek samping ketika sudah kembali ke rumah, diinformasikan tentang hal-hal yang membantu meningkatkan derajat kesehatan atau membantu agar bisa sembuh dan tidak kambuh, ingin memiliki satu orang petugas kesehatan yang selalu bisa dihubungi atau diajak bicara mengenai aspek kondisi mereka dan memiliki akses konseling yang profesional serta kemudahan dalam mengakses layanan terapi komplementer (Li et al., 2018; Urbaniec et al., 2011; Williams, Griffin, Farrell, Rea, Murray, \& Hauck, 2018; Zhu et al., 2018).

Pada kebutuhan fisik yang tidak terpenuhi adalah berhubungan dengan kelelahan atau kekurangan energi sehingga tidak dapat 
melakukan aktivitas bahkan hanya mampu bekerja dirumah saja atau hanya mampu melakukan aktivitas-aktivitas kecil di rumah (McCallum et al., 2014). Biasanya keluhan yang sering muncul adalah berhubungan dengan nyeri, kurang nafsu makan, efek samping pengobatan seperti kerontokan rambut bahkan mengalami insomnia (Afiyanti et al., 2019; Hediya Putri et al., 2018; Williams, Griffin, Farrell, Rea, Murray, \& Hauck, 2018). Pada studi Beesley, Price, Webb \& Rourke, (2013), mengatakan bahwa kebutuhan setiap individu berbeda setiap durasi waktu bertahan hidup para penyintas kanker dimana hasil yang didapatkan untuk domain fisik pada bulan pertama atau post pengobatan terakhir keluhan fisik memang paling dominan tetapi pada dua belas bulan berikutnya akan berkurang dan dua puluh empat bulan selanjutnya masih konstan dengan masalah pada fisiknya.

Pada studi lainnya $67 \%$ dari sampel melaporkan setidaknya satu masalah kesehatan seksual yang belum terpenuhi dan melaporkan bahwa mereka merasa khawatir tentang kehidupan seks mereka, melaporkan kesulitan dengan perubahan kesehatan seksual. Selain itu, pada alat ukur The Sexual Function-Vagial changer Questionnaire (SVQ) dari item SVQ mengungkapkan bahwa tidak semua perempuan yang mengalami dispareunia dan kekeringan terganggu oleh atau kesulitan dalam berhubungan seksual. Misalnya, 70\% perempuan yang aktif secara seksual mengalami dispareunia, tetapi hanya 50\% yang terganggu. Permasalahan lainnya termasuk strategi manajemen gejala (misalnya, penggunaan pelumasan), faktor hubungan (misalnya, kesehatan seksual pasangan, komunikasi) memerlukan perhatian dari pelayanan kesehatan (Doubova, \& Perez-Cuevas, 2020).

Penyintas kanker ginekologi memiliki kebutuhan informasi tentang kesehatan seksual, dimana penyintas mengatakan bahwa kurangnya informasi dan ketidaktahuan terhadap perubahan kemampuan dalam berhubungan seksual paska pengobatan kanker. Sekitar $40 \%$ informasi tentang hal ini tidak didapatkan oleh penyintas sehingga terjadi penurunan keinginan untuk melakukan hubungan seksual, rasa takut terhadap penyakit dan takut terhadap rasa sakit melakukan hubungan seksual (Cho et al, 2020).
Setelah selesai menjalani terapi menginginkan informasi tentang kapan boleh melakukan hubungan seksual serta semua informasi tentang hubungan seksual. Bagi yang belum menikah mungkin lebih ke bagaimana perasaan mereka terhadap masa depan tentang memiliki anak dan juga menjaga kesehatan sistem reproduksinya setelah selesai semua tahap pengobatan Pongthavornkamol, Lekdamrongkul, Pinsuntorn \& Molassiotis (2019). Pada studi lainnya menurut Williams, Griffin, Farrell, Rea, Murray \& Hauck (2018), mengatakan bahwa penyintas kanker juga akan mengalami perubahan kemampuan untuk melakukan hubungan seksual dan memiliki kekhawatiran yang tinggi terhadap bagaimana mereka bisa memenuhi kewajiban seksual sebagai seorang istri.

\section{PEMBAHASAN}

Seseorang dikatakan penyintas kanker yaitu sejak saat terdiagnosis, melalui keseimbangan dan perjuangan hidupnya, termasuk anggota keluarga, teman, dan pengasuh yang dipengaruhi oleh pengalaman bertahan hidup (Hewitt, Greenfield, Stovall, dan Policy, 2006; Khan, Rose dan Evans, 2012; Truant, Fitch, Oleary dan Stewart 2017). Populasi penyintas kanker terus bertambah yaitu sekitar $60 \%$ pada orang dewasa dan $78 \%$ pada anak-anak didiagnosis kanker dan mampu bertahan hidup selama lima tahun.

Banyak masalah muncul akibat kanker, pengobatan kanker seperti kemoterapi, radiasi, operasi yang berdampak terhadap fisik, emosional dan sosial seseorang dan dampak dari pengobatan kanker setelah terapi selesai (Mayer, Nasso, \& Earp, 2017). Pada studi yang dilakukan oleh Afiyanti, Milanti, \& Putri (2018) Afiyanti dan Gayatri (2019) menunjukkan bahwa setidaknya sekitar $98 \%$ akan ada satu kebutuhan yang tidak terpenuhi oleh para perempuan penyintas kanker ginekologi. Salah satu tools yang digunakan untuk mengidentifikasi kebutuhan apa saja yang belum terpenuhi pada para penyintas kanker ginekologi. Pada studi ini menggunakan CaSUN dan SCNS-SF 34 (McCallum et al., 2014; Rowlands, Janda, Mckinnon, webb \& Beesley, 2015; Williams, Griffin, Farrell, Rea, Murray, \& Hauck, 2018).

Studi menurut McCallum et al (2014) mengatakan bahwa kondisi fisik seseorang setelah menjalani serangkaian pengobatan 
terapi modalitas tidak sama seperti pasien sebelum terdiagnosis dikarenakan efek dari terapi sehingga masalah fisik seperti kelelahan sering sekali menjadi keluhan bagi para penyintas kanker ginekologi. Hal ini juga sejalan dari hasil studi Zhu et al (2018) dan Pongthavornkamol et al (2019) yang mengatakan bahwa meskipun masalah fisik yang terjadi pada domain rendah tetapi tetap saja akan mengganggu penyintas dalam beraktivitas.

Kebutuhan manusia tidak hanya terbatas pada kebutuhan secara fisik saja tetapi masih ada kebutuhan emosional, sosial, psikologi dan spiritual (Zhu et al., 2018). Pada perempuan penyintas kanker ginekologi juga memiliki kebutuhan-kebutuhan yang perlu dipenuhi. Kebutuhan perawatan suportif yang tidak terpenuhi dapat berkontribusi pada tekanan emosional dan mengurangi kualitas hidup para penyintas kanker (Fitch, Porter \& Beverley, 2009).

Kebutuhan seorang individu bervariasi dipengaruhi oleh sosial demografi seperti usia yang lebih muda, durasi bertahan hidup juga memengaruhi kebutuhan penyintas dan juga stadium kankernya (Li et al., 2018). Studi lain yang menurut Beesley, Alemayehu, \& Webb (2018), jika durasi waktu para penyintas kanker 6-12 bulan dengan 12 bulan dan > 24 bulan akan memiliki kebutuhan yang berbeda dimana pada sudi ini dikatakan jika bulan pertama kebutuhan yang paling sering tidak terpenuhi adalah pada domain psikologi yaitu tentang ketakutan akan penyakit kembali lagi sekitar $25 \%$ dan pada 12 bulan kemudian akan berkurang menjadi 16\% tetapi meningkat kembali pada $>24$ bulan kemudian begitu juga dengan domain pelayanan dan informasi kesehatan karena 2 domain ini paling dominan. Hal tersebut menjelaskan jika kebutuhan seseorang individu satu dengan yang lain berbeda dan berubah dari waktu ke waktu.

Dari hasil beberapa studi yang didapatkan kebutuhan yang dominan belum terpenuhi pada adalah pada domain psikologi dimana hampir pada temuan studi didapatkan bahwa penyintas kanker ginekologi mengkhawatirkan tentang takut penyakitnya kambuh atau kembali lagi, kemudian takut takut bahwa penyakit akan menyebar ditempat yang lain, kekhawatiran lainnya yaitu takut tidak dapat melakukan hal-hal yang biasa saya lakukan, takut tidak bisa kembali bekerja.
Muncul juga pikiran-pikiran tentang kematian , ketidakpastian masa depan, cemas dan mencoba mengendalikan situasi (McCallum et al., 2014; Williams, Griffin, Farrell, Rea, Murray, \& Hauck, 2018).

Penyintas kanker baik usia muda dan usia tua juga memengaruhi kebutuhan seseorang dimana jika masih berusia reproduktif kebutuhannya lebih kepada bagaimana memenuhi kebutuhan secara psikologis, fisik dan seksualnya, perawatan komprehensif dan lebih kepada hubungan baik personal maupun sosial mereka, sedangkan pada usia tua membutuhkan bagaimana pendekatan terhadap sistem pelayanan yang akan didapatkan, seksualitas dan juga kebutuhan akan spiritual mereka (Zhu et al., 2018).

Pada domain kebutuhan seksual menurut Zhu et al, (2018) mengatakan bahwa penyintas kanker di China memiliki pengalaman yang buruk terkait kondisi seksual paska terapi modalitas dimana mereka sangat minim sekali membahas dengan petugas kesehatan terkait masalah seksual ini karena dianggap sensitif dan malu. Sehingga masalah yang timbul pada domain seksual selain kejujuran dari pasien yang diperlukan, sering tidak diketahui secara pasti karena informasi yang didapatkan terkait masalah seksual tidak tergali dengan baik. Menurut hasil studi Cho et al (2020) mengatakan bahwa $40 \%$ penyintas kanker mengkhawatirkan kebutuhan seksual hal ini dikarenakan penyintas tidak mendapatkan informasi yang tepat terkait kapan mereka boleh kembali melakukan hubungan seksual dan ketakutan yang besar terkait nyeri atau perdarahan jika melakukan hubungan seksual.

Berdasarkan adanya empat domain yang sering muncul pada kebutuhan yang tidak terpenuhi yaitu domain tertinggi pada psikologis dan informasi pelayan kesehatan, serta domain terendah fisik dan kesehatan seksual, tetapi hal tersebut diatas memerlukan perhatian yang lebih bagi petugas kesehatan terutama yang melayani penyintas kanker ginekologi. Hal ini memang tergantung dari pelayanan kesehatan di setiap negara akan berbeda.

Pelayanan kesehatan di beberapa negara sangat berbeda dengan pelayanan kesehatan yang ada di Indonesia, dimana Indonesia merupakan negara yang memiliki beragam budaya, suku dan etnis. Budaya memiliki peran penting dalam pemberian 
pelayanan kesehatan terutama keperawatan yang sudah terintegrasi dalam memberikan pelayanan kesehatan berdasarkan peka budaya kepada pasien (Kemenkes, 2017).

Pelayanan kanker di Indonesia terutama di Rumah Sakit Rujukan Nasional maupun rumah sakit yang menerima pasien dengan kanker yang sudah memiliki pelayanan paliatif. Dimana pelayanan paliatif merupakan bentuk pelayanan terpadu yang bertujuan meningkatkan kualitas hidup pasien. Selain itu, memberikan dukungan spiritual dan psikososial mulai saat diagnosa sampai akhir hayat. Dukungan pun diberikan juga terhadap keluarga yang kehilangan, tetapi dari fasilitas pelayanan tersebut masih ada saja kebutuhan yang belum terpenuhi. Kebutuhan pada pelayanan dan informasi yang paling sering belum terpenuhi adalah kurangnya informasi tentang efek samping setelah selesai terapi pengobatan, informasi tentang tanda-tanda kekambuhan, informasi tentang tes-tes apa lagi yang akan didapatkan setelah selesai pengobatan atau seterusnya, pasien diperlakukan seperti bukan sakit kanker, (Rietveld, Husson, \& Vos, 2018; Rowlands, Janda, Mckinnon, webb \& Beesley, 2015; Williams, Griffin, Farrell, Rea, Murray, \& Hauck, 2018; Zhu et al., 2018). Keterbatasan dalam studi ini adalah hanya dibatasi pada seleksi studi Cross Sectional sehingga belum menggambarkan hasil data yang lebih bervariasi.

\section{KESIMPULAN DAN SARAN}

Kebutuhan pelayanan kesehatan bagi penyintas kanker semakin meningkat dimana secara fakta banyak masalah yang dialami perempuan penyintas kanker mulai saat terdiagnosis awal hingga terapi modalitas dilakukan. Penyintas kanker hidup dengan rasa ketidakpastian dari saat diagnosis. Banyak sekali masalah yang timbul dan minimal ada satu kebutuhan para penyintas yang tidak terpenuhi. Domain yang paling sering tidak terpenuhi adalah psikologi yaitu paling sering adalah takut penyakit kembali atau takut kambuh, Pada domain informasi kesehatan penyintas kanker memiliki kebutuhan yang perlu dipenuhi yaitu informasi tentang penyakit kanker mereka terkendali atau berkurang, mendapat informasi tentang efek samping setelah semua pengobatan selesai dilakukan, pada domain fisik yaitu masih tentang kelelahan, kehilangan energi yang paling dominan. Masalah kesehatan lainya yaitu seksual yang belum terpenuhi dimana dilaporkan bahwa mereka merasa khawatir tentang kehidupan seks mereka, melaporkan kesulitan dengan perubahan kesehatan seksual.

Mengingat semakin tingginya angka kejadian kanker didunia tidak terkecuali pada perempuan di Indonesia, serta semakin meningkat pula kebutuhan penyintas kanker ginekologi. Kebutuhan yang tidak terpenuhi secara psikologis, sosial dan spiritual serta informasi pelayanan kesehatan. Kebutuhan yang paling sering muncul pada psikologi yaitu tentang rasa takut terhadap kekambuhan kanker sehingga diharapkan dengan sistem pelayanan yang ada di Indonesia dan juga dengan beragam karakteristik individu yang berbeda-beda penelitian selanjutnya dapat mengeksplorasi hasil informasi pelayanan kesehatan pada kondisi psikologi terutama tentang rasa takut dan takut kambuh pada penyintas kanker ginekologi sehingga diharapkan dapat memberikan pelayanan kesehatan sesuai dengan kebutuhan pasien.

\section{DAFTAR PUSTAKA}

Afiyanti, Y., Milanti, A., \& Putri, R. H. (2018). Supportive care needs in predicting the quality of life among gynecological cancer patients. Winter Canadian Oncology Nursing, 28(1). https://doi.org/10.5737/23688076281222 9.

American Cancer Society. (2016). Cancer Treatment \& Survivorship Facts \& Figures 2016-2017. American Cancer Society, $44 . \quad$ https://doi.org/ $10.3322 /$ caac. 21235 .

American Cancer Society. (2018). Cancer Facts \& Figures. Diunduh dari https://www.cancer.org/content/dam/canc er-org/research/ cancer-facts-andstatistics/annual-cancer- facts-andfigures/2018/cancer-facts- and-figures2018.pdf.

Beesley, V. L., Alemayehu, C., \& Webb, P. M. (2018). A systematic literature review of the prevalence of and risk factors for supportive care needs among women with gynaecological cancer and their caregivers. Supportive Care in Cancer, 26(3), 701-710. https://doi.org/10.1007/ s00520-017-3971-6.

Bray, F., Ferlay, J., Soerjomataram, I., Siegel, 
R., Torre, L., \& Jemal, A. (2018). Global cancer statistics 2018: GLOBOCAN estimates of incidence and mortality worldwide for 36 cancers in 185 countries. A Cancer Journal for Clinicians, 1-31. https://doi.org/ 10.3322/caac.21492.

Doubova, S. V., Martinez-Vega, I. P., InfanteCastañeda, C., Aranda-Flores, C. E., Knaul, F. M., \& Pérez-Cuevas, R. (2020). Social inequalities in supportive care needs and quality of patient-centered care of cancer patients in Mexico. Supportive Care in Cancer, 1-13.

Fitch, M. I., Porter, H. B., \& Beverley D. Page. (2009). Supportive care framework : A Foundation for person-centred care. (M. I. Fitch, Ed.). Toronto, Canada.

Hediya Putri, R., Afiyanti, Y., Ungsianik, T., \& Milanti, A. (2018). Supportive care needs and quality of life of patients with gynecological cancer undergoing therapy. Enfermeria Clinica, 28, 222-226. https://doi.org/10.1016/S11308621(18)30 072.

Hewitt, M., Greenfield, S., Stovall, E., \& Policy, N. C. (2006). From Cancer Patient to Cancer Survivor - Lost in Transition. https://doi.org/10. 17226/11613.

Kemenkes. (2017) Kemenkes tingkatkan kesehatan masyarakat daerah melalui riset etnografi. Diunduh dari http://www.depkes.go.id/article/view/170 40400002/kemenkes- tingkatkankesehatan-masyarakat- daerah-melaluiriset-etnografi.html.

Khan, N. F., Rose, P. W., \& Evans, J. (2012). Defining cancer survivorship: A more transparent approach is needed. Journal of Cancer Survivorship, 6(1), 33-36. https://doi.org/10.1007/s11764-011-01946.

Li, Q., Lin, Y., Zhou, H., Xu, Y., \& Xu, Y. (2018). Supportive care needs and associated factors among Chinese cancer survivors : a cross-sectional study, 287295.

Mayer, D. K., Nasso, S. F., \& Earp, J. A. (2017). Defining cancer survivors, their needs, and perspectives on survivorship health care in the USA. The Lancet Oncology, 18(1), e11-e18. https://doi.org/10.1016/S14702045(16)30
573-3.

McCallum, M., Jolicoeur, L., Lefebvre, M., Babchishin, L. K., Robert-Chauret, S., Le, T., \& Lebel, S. (2014). Supportive Care Needs After Gynecologic Cancer: Where Does Sexual Health Fit in? Oncology Nursing Forum, 41(3), 297306. https://doi.org/10.1188/14.ONF.297306.

Ozga, M., Aghajanian, C., Myers-Virtue, S., McDonnell, G., Jhanwar, S., Hichenberg, S., \& Sulimanoff, I. (2013). A systematic review of ovarian cancer and fear of recurrence. Palliative and Supportive Care, 13(6), 1771-1780. https://doi.org/10.1017/S1478951515000 127.

Pongthavornkamol, K., Lekdamrongkul, P., Pinsuntorn, P., \& Molassiotis, A. (2019). Physical Symptoms, Unmet Needs, and Quality of Life in Thai Cancer Survivors after the Completion of Primary Treatment. Asia-Pacific journal of oncology nursing, 6(4), 363.

Rietveld, M. J. A., Husson, O., \& Vos, M. C. (Caroline). (2018). Association between information provision and supportive care needs among ovarian cancer survivors: A cross-sectional study from the profiles registry. https://doi.org/10.1002/pon. 4742.

Rowlands, I. J., Janda, M., McKinnon, L., Webb, P. M., Beesley, V. L., \& on behalf of the Australian National Endometrial Cancer Study Group. (2015). Prevalence, predictors, and correlates of supportive care needs among women 3-5 years after a diagnosis of endometrial cancer. Supportive Care in Cancer, 23(5), 12051214. https://doi.org/10.1007/s00520014-2456-0.

Simard, S., Thewes, B., Humphris, G., Dixon, M., Hayden, C., Mireskandari, S., \& Ozakinci, G. (2013). Fear of cancer recurrence in adult cancer survivors: A systematic review of quantitative studies. Journal of Cancer Survivorship, 7(3), 300-322. https://doi.org/10.1007/s11764013-0272-z.

Truant, T. L., Fitch, M. I., O'Leary, C., \& Stewart, J. (2017). Global perspectives on cancer survivorship: From lost in transition to leading into the future. CANO-ACIO/ONS/ISNCC Joint 
Symposium at the CANO-ACIO Conference in Calgary Alberta, 27(3), 287-304.

Urbaniec, O. A., Collins, K., Denson, L. A., \& Whitford, H. S. (2014). Gynecological cancer survivors: Assessment of psychological distress and unmet supportive care needs. Journal of Psychosocial Oncology, 29(5), 534-551. https://doi.org/10.1080/07347332.2011.5 99829.

Williams, N., Griffin, G., Farrell, V., Rea, A., Murray, K., \& Hauck, Y. L. (2018). The supportive care needs of women experiencing gynaecological cancer: a Western Australian cross-sectional study, $1-15$.

Zhu, L., Yao, J., Schroevers, M. J., Zhang, H., Xie, J., Liu, A., Song, Z. (2018). Patterns of unmet supportive needs and relationship to quality of life in Chinese cancer patients. Psycho-Oncology, 27(2), 600-606.

https://doi.org/10.1002/ 